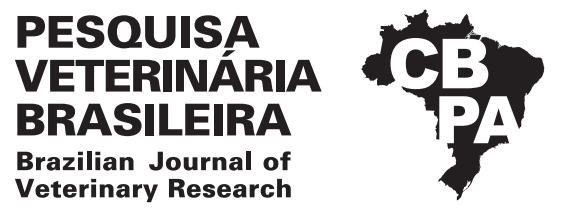

Pesq. Vet. Bras. 39(10):843-848, October 2019 DOI: 10.1590/1678-5150-PVB-6337

Original Article

Animal Morphophysiology

ISSN 0100-736X (Print)

ISSN 1678-5150 (Online)

\title{
Transition period produces changes in blood and body composition in mares ${ }^{1}$
}

\author{
Micheline O. Silva2* (D), Hélio C. Manso Filho ${ }^{3}$ (D), Bruna Maria Ribeiro² (D), \\ Pedro A.N. Ermita ${ }^{2}$ (D), Lorena C. Monteiro² (D), Caio M. Costa² (D), Samuel R. Alves ${ }^{2}$ (D) \\ and José D. Ribeiro Filho ${ }^{2}$ (D)
}

\begin{abstract}
Silva M.O., Manso Filho H.C., Ribeiro B.M., Ermita P.A.N., Monteiro L.C., Costa C.M., Alves S.R. \& Ribeiro Filho J.D. 2019. Transition period produces changes in blood and body composition in mares. Pesquisa Veterinária Brasileira 39(10):843-848. Departamento de Veterinária, Universidade Federal de Viçosa, Av. Peter Henry Rolfs s/n, Campus Universitário, Viçosa, MG 36570-900, Brazil. E-mail: michelineozana@gmail.com

Clinical and metabolic evaluation is necessary for the monitoring of pregnant and lactating mares, as they reflect the health of the animal. The body condition of the mare is an indicator of reproductive efficiency. The study aimed to determine the possible variations in body and metabolic condition in Mangalarga Marchador mares during the transition period. Forty-eight mares distributed in two groups were used: Maintenance Group (MG), composed of non-pregnant and non-lactating mares, and Transition Group (TG), formed by pregnant mares and who after delivery became lactating. Analyzes were performed in the times T-60, T-30 and T-15 before delivery, first six hours (T0) after delivery and T15, T30 and T60 days after delivery. MG was evaluated only at one time (T-60). Body weight and fat-free mass differed $(\mathrm{P}<0.05)$ between the groups. The percentage of fat was lower in MG. Mares had a higher fat percentage in TG at T-60 and T-30 times. There was a difference $(\mathrm{P}<0.05)$ in the amount of cholesterol between MG and TG (T0, T15 and T30). Triglycerides were different between the groups. TG showed higher concentrations of non-esterified fatty acids $(\mathrm{P}<0.05)$. There was a higher amount of glucose in TG (delivery and lactation) when compared to mares in MG. Changes in body condition and metabolic constituents occurred in the animals resulting from physiological adaptations of the transition period. The energetic components are the most affected from the transition period, with intense fat mobilization to supply the body demands.
\end{abstract}

INDEX TERMS: Transition period, blood, body composition, mares, clinical evaluation, Mangalarga Marchador, pregnancy, percentage of fat, equine.

\footnotetext{
RESUMO.- [Período de transição produz alterações na composição do sangue e do corpo em éguas.] Avaliações clínicas e metabólicas são necessárias para o monitoramento de éguas gestantes e lactantes, pois refletem a saúde do animal. A condição corporal da égua pode ser um indicador da eficiência reprodutiva. 0 estudo objetivou determinar as

${ }^{1}$ Received on May 10, 2019.

Accepted for publication on May 30, 2019.

${ }^{2}$ Graduate Studies Program in Veterinary Medicine, Departamento de Veterinária, Universidade Federal de Viçosa (UFV), Av. Peter Henry Rolfs s/n, Campus Universitário, Viçosa, MG 36570-900, Brazil. *Corresponding author: michelineozana@gmail.com

${ }^{3}$ Graduate Studies Program in Veterinary Medicine, Departamento de Zootecnia, Universidade Federal Rural de Pernambuco (UFRPE), Rua Dom Manuel de Medeiros s/n, Dois Irmãos, Recife, PE 52171-900, Brazil.
}

possíveis variações na condição corporal e metabólica em éguas Mangalarga Marchador durante o período de transição. Foram utilizadas 48 éguas distribuídas em dois grupos: Grupo em Manutenção (GM) composto por éguas não gestantes e não lactantes; Grupo em Transição (GT) formado por éguas gestantes e que após o parto tornaram-se lactantes. As análises foram realizadas nos tempos T-60, T-30 e T-15 antes do parto, primeiras seis horas (T0) após o parto e T15, T30 e T60 dias após o parto. 0 GM foi avaliado apenas uma vez (T-60). 0 peso corporal e a massa livre de gordura diferiram $(\mathrm{P}<0,05)$ entre os grupos. 0 percentual de gordura foi menor em GM. As éguas apresentaram maior porcentagem de gordura no GT no T-60 e no T-30. Houve diferença $(\mathrm{P}<0,05)$ na quantidade de colesterol entre GM e GT (T0, T15 e T30). Triglicérides foram diferentes entre os grupos. GT apresentou maiores 
concentrações de ácidos graxos não esterificados $(\mathrm{P}<0,05)$. Houve maior quantidade de glicose no GT (parto e lactação) quando comparada às éguas no GM. Mudanças na condição corporal e nos constituintes metabólicos ocorreram nos animais resultantes de adaptações fisiológicas do período de transição. Os componentes energéticos são os mais afetados neste período, existindo intensa mobilização de gordura para suprir demandas corporais.

TERMOS DE INDEXAÇÃO: Período de transição, composição do sangue, corpo, éguas, avaliação clínica, Mangalarga Marchador, gravidez, porcentagem de gordura, sangue, equinos.

\section{INTRODUCTION}

The time interval between the end of pregnancy, delivery, and early lactation is called the transition period (Manso Filho et al. 2008). In mares, successive changes occur in the maternal organism during pregnancy, typically in the anabolic phase, in preparation for the end of pregnancy, parturition and early lactation, which represent the catabolic phase. The metabolic events are known to be adaptive mechanisms of the body in the transition from pregnancy to lactation (Hura et al. 2017). These continuous changes in the anabolism-catabolism cycle are dependent on the management system and affect the metabolism of all nutrients to ensure that the nutritional requirements of the fetuses and newborns are being met. These important events are relevant for the formation of a future athlete horse.

Understanding the relationship between body fat and reproductive efficiency of embryo donor mares during strategic phases of equine physiology allows the creation of a nutritional and management program appropriate to their body conditions. Deposition of adipose tissue differs between pregnant and nonpregnant mares and causes changes in anatomical conformation. In pregnant mares, the layer of fat is reduced in the dorsal region, ribs, and the base of tail, being most prominent in the region of the withers of scapula (Henneke et al. 1983).

Assessment of body condition is used to determine the reproductive efficiency in mares (Rodrigues et al. 2011) and when combined with laboratory tests, improves reproductive efficiency among mares and survival rates of newborns. To assess the body condition of breeding mares, different methods are available and can be used, such as the determination of the body score index, which is a subjective method of assessing body fat and muscles (Henneke et al. 1983). Furthermore, the determination of the body fat percentage has recently been carried out using ultrasound equipment, providing an objective measure that is efficiently replicable by veterinarians. Knowledge of the body fat percentage can contribute to the assessment of nutritional management and training practices (Manso Filho et al. 2009).

Body modifications are associated with changes in different blood biomarkers, the main ones being related to the energy metabolism of both carbohydrates and fats. An example is the loss of lean body mass during lactation, which may indicate the occurrence of protein mobilization of the skeletal muscle to provide amino acid precursors for milk and gluconeogenesis required for the synthesis of lactose, however, this loss might be harmful to the mare's future performance (Manso Filho et al. 2008).
In view of the fact of the importance of the metabolic status relationship between mare and their fetuses/newborns and because of the scarcity of available studies addressing the topic, the present study aimed to determine the variations in body and metabolic condition in Mangalarga Marchador mares during the transition period.

\section{MATERIALS AND METHODS}

Ethics statement. The study was conducted in Salgada Farm, located in the city of Itaperuna, Rio de Janeiro, Brazil. The study was approved by the Committee on Ethics in the Use of Animals (CEUA) of the "Universidade Federal de Viçosa" (protocol no. 95/2015).

Animals and breeding system. Forty-eight Mangalarga Marchador mares (aged 5 to 15 years) were distributed in two groups: Maintenance Group (MG), composed of non-pregnant and non-lactating mares, and Transition Group (TG), formed by pregnant mares and who after delivery became lactating. At the farm, the animals were kept under extensive management. All mares that were selected in the study were kept in pastures, with Tifton grass (Cynodon spp.), water and commercial mineral salt (Coequi Plus, Tortuga) available ad libitum, without supplementation of concentrates. Two weeks prior to the delivery, the mares were transferred to maternity paddocks, maintaining the diet, where they were kept until the time of delivery.

Evaluation of body condition. All mares were weighed on a calibrated scale with a measuring capacity of up to $1.000 \mathrm{~kg}$. The body fat percentage was determined by the measurement of the thickness of the fat layer in the rump, as described by Manso Filho et al. (2009). An ultrasound (SonoSite 180 PLUS, Sonosite FujiFilm, Sao Paulo/SP, Brazil) with a $10-5 \mathrm{MHz}$ linear transducer was used. A midpoint was drawn between the tuberosity of the ischium and the ilium, approximately $10 \mathrm{~cm}$ from the midline of the body, and at this point, the fat layer (FL) was measured. The measurement was always on the same side and was made by the same evaluator. Body fat percentage (BFP) was obtained as follows: $[\mathrm{BFP}=8.64+(4.7 \times \mathrm{FL})]$. Thus, the fat-free mass was determined by calculating the body weight difference by the body fat percentage of each mare, and the results were presented in kilograms (kg).

Metabolic profile. Blood samples for serum and plasma obtain were collected at seven times: T-60, T-30, T-15, T0 (first 6 hours after delivery), T15, T30 and T60. The samples were taken without prior fasting using disposable needles. Flasks containing sodium fluoride were used to obtain plasma and siliconized vials without anticoagulant were used for serum acquirement. The samples were processed, aliquoted into microtubes and immediately frozen at $-20^{\circ} \mathrm{C}$ until the time of the laboratory analysis. Biochemical analyses were performed on a Humastar 300 automatic device (Humano, In Vitro Diagnóstica Ltda., Itabira/MG, Brazil).

The serum total cholesterol (Enzymatic Colorimetric Method with Lipid Clearing Factor, In Vitro Diagnóstica Ltda, Itabira/MG, Brazil), triglycerides (Colorimetric Enzymatic Method with Lipid Clearing Factor, In Vitro Diagnóstica Ltda, Itabira/MG, Brazil), and non-esterified fatty acid (NEFA) (Colorimetric Method, Randox, Centerkit, Ribeirão Preto/SP, Brazil) levels and the plasma concentrations of glucose (Enzymatic Colorimetric Method without deproteinization, In Vitro diagnóstica Ltda, Itabira/MG, Brazil) were measured.

The body condition of TG mares was evaluated at the following time points: T-60 (60 days before delivery), T-30 (30 days 
before delivery), T-15 (15 days before delivery), T15 (15 days after delivery), T30 (30 days after delivery) and T60 (days after delivery). MG mares were evaluated only once (first collection of all "T-60" animals).

Statistical analysis. To analyze the data, the Statistical Analysis System (SAS) was used (SAS 2002). The data were evaluated using the Kolmogorov-Smirnov and Bartlett's tests to verify the normality of the errors and homogeneity of variances, respectively, and the variables that did not satisfy the ANOVA assumptions were submitted to the square root transformation $\left[\mathrm{y}^{\wedge^{\prime}}=\sqrt{ }(\mathrm{y}+0.5)\right]$.

The data for pregnant mares were analyzed in linear mixed models with repeated plots in time using PROC MIXED (SAS 2002), with autoregressive and animal covariance structure as random effect (Littell et al. 2006), according to the mathematical model: $Y_{i j}=X_{i j k} \beta_{k}+Z_{i j k} b_{i k}+e_{i j}$. For the comparison of means (least square means), the t-test with Tukey-Kramer adjustment was used for the low instability variables ( $\mathrm{CV}<15 \%)$, and the means were adjusted by the t-test for unstable variables ( $C V>15 \%)$. In addition, the means of the times were compared to the MG using the Dunnett's test. The level of significance was $\alpha=0.05$.

\section{RESULTS}

During the entire experimental period, mean ambient temperatures (minimum and maximum) were $17.4^{\circ} \mathrm{C}$ and $28.6^{\circ} \mathrm{C}$, respectively, and the mean relative humidity of the air was $49 \%$. The evaluations were always performed from 9 to $11 \mathrm{a} . \mathrm{m}$. and by the same evaluators. No intercurrences with the mares (abortion, inflammation, infections or parasitic diseases) were reported that could compromise the study.

The body weight (Fig.1) and fat-free mass (Fig.2) of the mares showed decreased values during the study. A difference was observed in both $M G$ variables $(\mathrm{P}<0.05)$ when compared to TG at T-60, T-30, and T-15 times (pregnant mares). Over time, body weight and fat-free mass decreased progressively $(\mathrm{P}<0.05)$. The percentage of body fat (Fig.3) was lower in MG mares. A difference between MG $(\mathrm{P}<0.05)$ and $T G$ at T-60 and T-30 times was observed. In the evaluation over time $(\mathrm{P}<0.05)$, the animals of the T-60 and T-30 showed higher percentage of fat than the animals of times T-15, $\mathrm{T} 15, \mathrm{~T} 30$, and $\mathrm{T} 60$, that maintained the percentage of fat without change.

The serum cholesterol concentration was different $(\mathrm{P}<0.05)$ between MG and TG at T0, T15, and T30 times, with a higher mean value observed in the first six hours postpartum (T0). The mares of the MG and TG groups (T-60, T-30, T-15, T0, and T60) showed average concentration within the reference values for the equine species. Mares evaluated at T15 and T30 times showed a cholesterol concentration below the reference values. A difference $(\mathrm{P}<0.05)$ was found over time in the animals evaluated in the transition period (Table 1).

The concentration of triglycerides remained within the reference values for the equine species. A difference $(\mathrm{P}<0.05)$ was observed between the $\mathrm{MG}$ and $\mathrm{TG}$ mares (T-30, T-15, T0, T15, and T30) (Table 1). In the evaluation over time, the mares of TG showed a progressive increase $(\mathrm{P}<0.05)$ in the amount of triglycerides in the T-60, T-30, and T-15 periods, showing a higher value at T-15 when compared with the other time periods evaluated. In the T0 $(\mathrm{P}<0.05)$ a

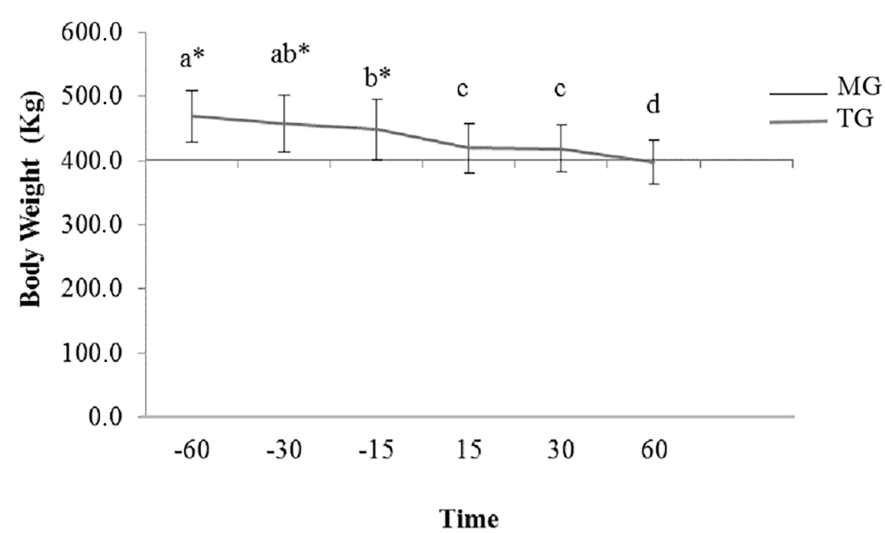

Fig.1. Mares body weight in maintenance (MG) and transition (TG) group. Lowercase letters differ the TG over time $(\mathrm{P}<0.05)$ by the Tukey test. Letters followed by * differ $(\mathrm{P}<0.05)$ from the MG by the Dunnet test.

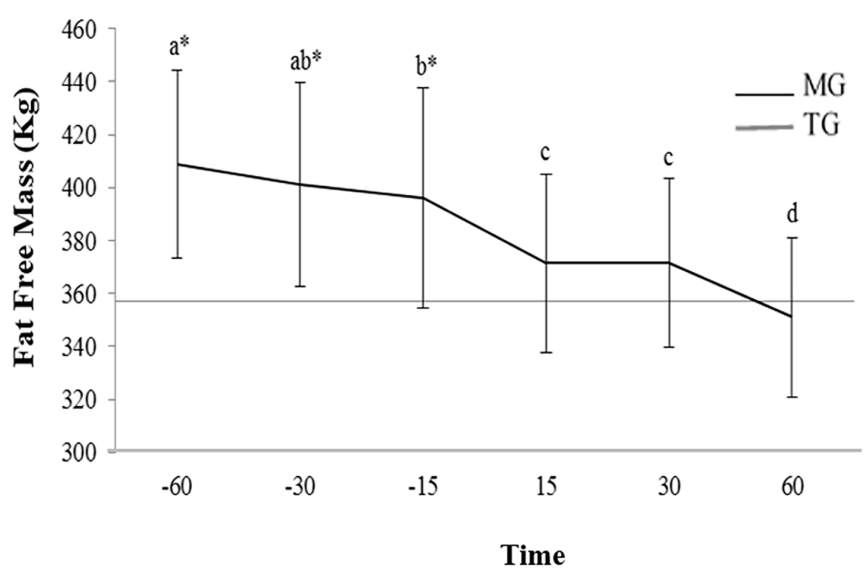

Fig. 2. Mares fat free mass in maintenance (MG) and transition (TG) group. Lowercase letters differ the TG over time $(\mathrm{P}<0.05)$ by the Tukey test. Letters followed by ${ }^{*}$ differ $(\mathrm{P}<0.05)$ from the MG by the Tukey test.

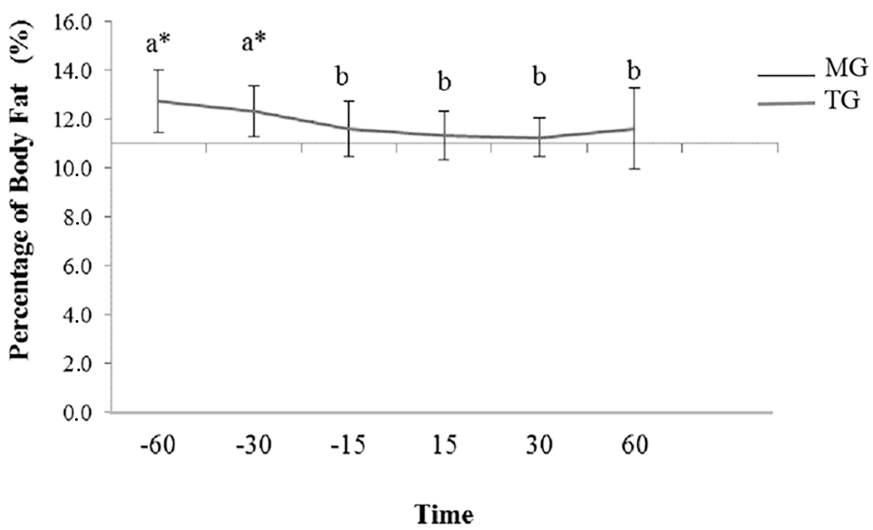

Fig.3. Percentage of body fat of mares in maintenance (MG) and transition (TG) group. Lowercase letters differ the GT over time $(\mathrm{P}<0.05)$ by the Tukey test. Letters followed by * differ $(\mathrm{P}<0.05)$ from the MG by the Dunnet test. 
Table 1. Mean values and standard deviation of the concentrations of cholesterol - CHOL (mmol/L), triglycerides - TRIGLY (mmol/L), non-esterificate fatty acids - NEFA (mmol/L) and glucose - GLU (mmol/L) evaluated in the Transition Group (TG) and Maintenance Group (MG)

\begin{tabular}{|c|c|c|c|c|c|c|c|c|}
\hline \multirow{3}{*}{$\begin{array}{c}\text { Blood } \\
\text { parameters }\end{array}$} & \multicolumn{7}{|c|}{ Times - TG } & \multirow{3}{*}{$\frac{M G}{\mathrm{~T}-60}$} \\
\hline & \multicolumn{3}{|c|}{ Pregnancy } & \multirow{2}{*}{$\begin{array}{c}\text { Delivery } \\
\text { T0 }\end{array}$} & \multicolumn{3}{|c|}{ Lactation } & \\
\hline & $\mathrm{T}-60$ & $\mathrm{~T}-30$ & $\mathrm{~T}-15$ & & $\mathrm{~T} 15$ & T30 & T60 & \\
\hline CHOL & $2.3 \pm 0.3^{b}$ & $2.5 \pm 0.5^{\mathrm{ab}}$ & $2.5 \pm 0.5^{b}$ & $2.9 \pm 0.6^{\mathrm{Aa}}$ & $1.7 \pm 0.3^{\mathrm{Acd}}$ & $1.6 \pm 0.3^{\mathrm{Ad}}$ & $1.9 \pm 0.3^{c}$ & $2.3 \pm 0.3$ \\
\hline TRIGLY & $0.3 \pm 0.1^{\mathrm{b}}$ & $0.5 \pm 0.2^{\mathrm{Aab}}$ & $0.5 \pm 0.2^{\mathrm{Aa}}$ & $0.4 \pm 0.2^{\mathrm{Aab}}$ & $0.1 \pm 0.0^{\mathrm{Ac}}$ & $0.1 \pm 0.0^{\mathrm{Ac}}$ & $0.1 \pm 0.0^{c}$ & $0.2 \pm 0.2$ \\
\hline NEFA & $0.3 \pm 0.1^{\mathrm{bc}}$ & $0.5 \pm 0.2^{\mathrm{Aab}}$ & $0.3 \pm 0.2^{\mathrm{abc}}$ & $0.5 \pm 0.2^{\mathrm{Aa}}$ & $0.4 \pm 0.2^{\mathrm{Aabc}}$ & $0.4 \pm 0.2^{\mathrm{Aabc}}$ & $0.2 \pm 0.1^{\mathrm{c}}$ & $0.2 \pm 0.1$ \\
\hline GLU & $5.3 \pm 0.4^{\mathrm{ab}}$ & $5.5 \pm 0.4^{\mathrm{ab}}$ & $5.0 \pm 0.4^{\mathrm{b}}$ & $5.6 \pm 1.1^{\mathrm{Aa}}$ & $4.1 \pm 0.4^{\mathrm{Ac}}$ & $3.9 \pm 0.4^{\mathrm{Ac}}$ & $4.1 \pm 0.5^{\mathrm{Ac}}$ & $5.1 \pm 0.4$ \\
\hline
\end{tabular}

Means followed by lower case letters on the same line differ $(\mathrm{P}<0.05)$ by the Tukey test, means followed by capital letters in the same row differ $(\mathrm{P}<0.05)$ in the MG by Dunnet's test.

reduction in triglycerides was noted, the lowest values being observed at T15, T30, and T60.

The lowest serum concentration of NEFA $(\mathrm{P}<0.05)$ was obtained in MG when compared to TG (Table 1). A difference $(\mathrm{P}<0.05)$ was found in the TG animals at all evaluated times, with a higher amount in the T0. During the lactation phase (after T0), there was a progressive reduction of the values.

A difference $(\mathrm{P}<0.05)$ in the plasma glucose concentration between the MG and TG groups at T0, T15, T30, and T60 was found. Higher amount of glucose was observed at T0. Over time, a difference $(\mathrm{P}<0.05)$ was found between the times evaluated (Table 1). The mares evaluated at T15, T30, and T60 showed values below the reference values for the equine species.

\section{DISCUSSION}

In the transition period, significant changes occurred in the body condition and in the metabolic components of the mares. The results showed that the final third trimester of pregnancy, delivery, and onset of lactation promote changes in the maternal organism, compatible with the results found in other studies (Harvey et al. 2005, Bazzano et al. 2014, Mariella et al. 2014). Knowledge of these changes is fundamental for the identification of diseases that can compromise the health of the mare, fetus and development of the foal.

The good health condition of the mares during the experimental period allowed a more accurate evaluation of the body and metabolic condition of the animals. This is the first study that evaluated Mangalarga Marchador mares during the transition period, although several studies have been carried out with the same purpose in mares of different breeds and during different stages of pregnancy, delivery and lactation (Hunka et al. 2015, Marchiori et al. 2015).

To produce valuable animals, some breeders changed the animal management, such as feeding with highly energetic food (Paz et al. 2013), which may predispose the breeding animal to develop metabolic disorders and obesity (Marchiori et al. 2015). Therefore, body weight, fat percentage and fat-free mass evaluation during the transition period in mares is crucial to make appropriate changes in the management of the animals to avoid the development of disorders.

Weight gain during pregnancy is caused by fetal growth, placental development and increased deposition of adipose tissue to achieve energy demands at the end of gestation and during lactation. However, in the transitional period, the progressive loss of body weight and the percentage of body fat around parturition is due to the negative energy balance during in this period. Reduced food intake, with increased fetal metabolic demands, foaling, and milk production to provide nutritional requirements for foals (Hura et al. 2017) may be one of the major reasons for weight and body fat losses. Animals submitted to higher metabolic demands have lower fat percentages (Manso Filho et al. 2009). The first study identifying changes in body composition in mares during the transition period was conducted by Manso Filho et al. (2008). The authors realized that during lactation, mares lost lean body mass as they maintained their body fat and that this fact can be explained since late gestation represents a mild catabolic state, that intensifies after delivery due to lactation. Similar findings were observed in the present study.

Marchiori et al. (2015) revealed a linear increase in the body weight of Crioulo mares from eight to eleven months. The authors suggested that weight gain that occurs in pregnant mares in the final third trimester of pregnancy, leads to a reserve of energy that is meant for use during lactation. This did not occur in our study, wherein a progressive reduction in the mean body weight values from T-60 to T60 was observed. Lawrence et al. (1992) suggest that pregnant mares may increase their body fat reserve during mid-gestation and then mobilize part of this reserve until delivery. These studies did not evaluate the food intake of the animals, as in the present study. For this reason, it cannot be affirmed that weight gain is a consequence of increased food intake. However, it is clear that in the last trimester of pregnancy and onset of lactation, a progressive loss of body weight is observed, which may be due to the mobilization of energy reserves owing to higher fetal demand.

Pregnancy and lactation resulted in increased metabolic requirements. Although homeostatic mechanisms act to maintain the concentration of nutrients in the blood at a relatively constant level, some variations are likely to occur (Harvey et al. 2005). According to Hunka et al. (2015), the lactating period is a challenge for mares, as the number of nutrients available in breast milk must meet the nutritional demands of foals.

Cholesterol is an important sterol in mammals, playing an important role in several physiological stages (Vasilenko 2016). The concentration of cholesterol in the blood can suffer influence from factors such as the amount of food that is ingested and absorbed as well as the portion synthesized in the liver and the amount that is reabsorbed (Aoki \& Ishii 2012). The cholesterol decreases slightly early in gestation 
and then increases progressively. Its concentration at the end of pregnancy rises by approximately $50 \%$ when compared to that in the non-pregnant state. However, these values slowly return to normal (15 to $20 \%$ ) by the second week postpartum (Hadden \& Mclaughlin 2009).

Initially, the reduction in the amount of cholesterol during gestation may be the result of factors such as plasma hemodilution, decreased secretion of liver lipoproteins, transport of cholesterol from the maternal body to the fetus and the increased use for the biosynthesis of steroid hormones. According to Vasilenko (2016), it is probable that the increase in cholesterol concentration is necessary for an increased rate of synthesis of hormones during pregnancy; besides, the high cholesterol observed during pregnancy may also be secondary to the increase in hormones associated with pregnancy. The pick of serum cholesterol concentration was in the first six hours after delivery and its progressive reduction during the first 30 days after lactation is reflective of the increased energy demand in mares.

Triglyceride is a key nutrient at the transition period, as it is the main component of adipose tissue and milk (Aoki \& Ishii 2012). In the last trimester of pregnancy, higher concentrations of this lipid were observed owing to the greater anabolic activity and increase in fat metabolism, necessary for fetal growth (Vincze et al. 2015). In a study by Harvey et al. (2005), significant differences were observed in different variables of mares when comparing pregnancy with the lactation period. The total concentration of triglycerides was reduced during lactation. Bazzano et al. (2014) also observed a significant reduction in the triglyceride levels after delivery. Although these studies differed with regard to breeds, times, and management, the concentration of triglycerides was similar to that obtained in this study. Hadden \& McLaughlin (2009) explain that triglyceride levels decrease gradually after delivery, returning to non-gestational values close to the second week postpartum. The concentrations of NEFA are used as indicators of lipid degradation in adipose tissue (Aoki et al. 2016) and reflect the status of the energy balance of the body (Hura et al. 2017). When animals enter a negative energetic balance, the organism signals the need to mobilize stored energy, the secretion of epinephrine occurs, which acts on adipose tissue, potentiating fat breakage and a resultant increase in NEFA values (Frape 2004, Aoki \& Ishii 2012). In addition, within about three days after calving, the free fatty acid levels fall to non-pregnant values (Hadden \& McLaughlin 2009). On the basis of other studies, Hura et al. (2017) explain that the increase in the concentration of NEFA and reduction in triglyceride levels after birth prove that mares compensate the negative energy balance by mobilization of fat reserves.

The glucose concentration in the fetus is $15 \%$ to $20 \%$ lower than in the mother (Hadden \& McLaughlin 2009) and in this way, facilitates the glucose transport from mother to fetus to supply the energetic demands. Glucose is the main component for fetal growth; however, during the end of gestation, its distribution remains constant, because the fetus begins to require energy from other substrates such as lactate and amino acids (Manso Filho et al. 2008).

Mares use glucose as a source of energy, and a change in their concentration may be due to an imbalance in the regulatory hormone (e.g., insulin) or excessive intake of energy sources. Mariella et al. (2014) explain that a higher concentration of glucose occurs at birth. The increase in the glucose concentration in mares may be associated with the physical stress which the animals are subjected during foaling (Aoki \& Ishii 2012). According to Vincze et al. (2015), changes in glucose regulation during pregnancy may be associated with the development of insulin resistance as well as a secondary increase in the plasma triglyceride concentration. The decrease in the concentration of glucose from lactation, in turn, is because of the greater demand by the mammary gland for obtaining energy and for lactose synthesis (Mundim et al. 2007).

\section{CONCLUSIONS}

It is possible to conclude that the changes in the body condition and metabolic components of the animals result from physiological adaptations during the transition period. The energetic components are the most affected from the transition period with intense fat mobilization to supply the body demands.

These evaluations are necessary to the species, during the period, as they reflect the health of the animals, allowing possible interventions in non-physiological cases.

Acknowledgements.- The authors are grateful to the "Coordenação de Aperfeiçoamento de Pessoal de Nível Superior" (CAPES) and the "Fundação de Amparo à Pesquisa do Estado de Minas Gerais” (FAPEMIG) for financial support.

Conflict of interest statement.- The authors have no competing interests.

\section{REFERENCES}

Aoki T. \& Ishii M. 2012. Hematological and biochemical profiles in peripartum mares and neonatal foals (Heavy Draft Horse). J. Equine Vet. Sci. 32(3):170176. <http://dx.doi.org/10.1016/j.jevs.2011.08.015>

Aoki T., Kimura Y., Oya A., Chiba A., Ishii M. \& Nambo Y. 2016. Hematological and biochemical features of postpartum fever in the heavy draft mare. J. Equine Sci. 27(1):13-16. <http://dx.doi.org/10.1294/jes.27.13><PMid:27073331>

Bazzano M., Giannetto C., Fazio F., Arfuso F., Giudice E. \& Piccione G. 2014 Metabolic profile of broodmares during late pregnancy and early postpartum. Reprod. Domest. Anim. 49(6):947-953.<http://dx.doi.org/10.1111/ rda.12411><PMid:25251226>

Frape D.L. 2004. Equine Nutrition and Feeding. 3rd ed. Blackwell Publishing, Oxford. 650p. <http://dx.doi.org/10.1002/9780470751053>

Hadden D.R. \& McLaughlin C. 2009. Normal and abnormal maternal metabolism during pregnancy. Semin. Fetal Neonatal Med.14(2):66-71. <http://dx.doi org/10.1016/j.siny.2008.09.004><PMid:18986856>

Harvey J.W., Pate M.G., Kivipelto J. \& Asquith R.L. 2005. Clinical biochemistry of pregnant and nursing mares. Vet. Clin. Pathol. 34(3):248-254. <http:// dx.doi.org/10.1111/j.1939-165X.2005.tb00049.X> <PMid:16134073>

Henneke D.R., Potter G.D., Kreider J.L. \& Yeates B.F. 1983. Relationship between condition score, physical measurements and body fat percentage in mares. Equine Vet.J. 5(4):371-372.<http://dx.doi.org/10.1111/j.2042-3306.1983. tb01826.x> <PMid:6641685>

Hunka M.M., Silva E.R.R., Vaz S.G., Ferreira L.M.C., Manso H.E.C.C.C. \& Manso Filho H.C. 2015. Avaliação hematológica de éguas em lactação mantidas a pasto. Ciênc. Vet. Tróp. 18:323-325.

Hura V., Novotný F., Valocký I., Boldizar M., Bílek J., Hornáková P., Vilhanová Z., Horňák S. \& Petrovič V. 2017. Changes of biochemical environment 
and body weight in healthy periparturient Lipizzan mares. Acta Vet. Brno 86(1):67-64. <http://dx.doi.org/10.2754/avb201786010067>

Lawrence L.M., Dipietro J., Ewert K., Parrett D., Moser L. \& Powell D. 1992. Changes in body weight and condition of gestating mares. J. Equine Vet. Sci. 12(6):355-358. <http://dx.doi.org/10.1016/S0737-0806(06)81361-4>

Littell R.C., Milliken G.A., Stroup W.W., Wolfinger R.D. \& Schabenberger 0. 2006. AS ${ }^{\circledR}$ for mixed models. 2nd ed. SAS Institute Inc., Cary, North Carolina. 814p.

Manso Filho H.C., McKeever K.H., Gordon M.E., Costa H.E.C., Lagakos W.S. \& Watford M. 2008. Changes in glutamine metabolism indicate a mild catabolic state in the transition mare. J. Anim. Sci. 86(12):3424-3431. <http://dx.doi.org/10.2527/jas.2008-1054><PMid:19036697>

Manso Filho H.C., Manso H.E.C.C., Ferreira L.M.C., Santiago T.A., Wanderley E.K. \& Abreu J.M.G. 2009. Percentagem de gordura de cavalos criados em região tropical. Acta Scient. Vet. 37(3):239-243. <http://dx.doi. org/10.22456/1679-9216.16336>

Marchiori M.O., Kasinger S., Silva K.R., Souza L.S., Amaral L.A., Nogueira C.E.W. \& Roll V.F.B. 2015. Medidas comparativas do padrão morfométrico e perfil energético de éguas Crioulas no terço final da gestação, com diferentes escores corporais. Arq. Bras. Med. Vet. Zootec. 67(3):707-715. <http:// dx.doi.org/10.1590/1678-4162-7705>

Mariella J., Pirrone A., Gentilini F. \& Castagnetti C. 2014. Hematologic and biochemical profiles in Standardbred mares during peripartum. Theriogenology 81(4):526-534.<http://dx.doi.org/10.1016/j.theriogenology.2013.11.001> <PMid:24361129>

Mundim A.V., Costa A.S., Mundim S.A.P., Guimarães E.C. \& Espindola F.S. 2007. Influência da ordem e estádios da lactação no perfil bioquímico sangüíneo de cabras da raça Saanen. Arq. Bras. Med. Vet. Zootec. 59(2):306-312. <http://dx.doi.org/10.1590/S0102-09352007000200006>

Paz C.F.R., Paganela J.C., Santos C.A., Nogueira C.E.W. \& Faleiros R.R. 2013. Relação entre obesidade, insulina plasmática e posicionamento da falange distal em equinos da raça Crioula. Arq. Bras. Med. Vet. Zootec. 65(6):16991705. <http://dx.doi.org/10.1590/S0102-09352013000600017>

Rodrigues P.G., Raymundo C.M., Souza J.C., Miranda M.C.M.G. \& Rezende A.S.C. 2011. Gordura corporal e eficiência reprodutiva em éguas doadoras de embrião Mangalarga Marchador. Ciênc. Agrotec. 35(5):1002-1008. <http:// dx.doi.org/10.1590/S1413-70542011000500019>

SAS 2002. SAS/STAT ${ }^{\circledR} 9.0$ User's guide. SAS Institute Inc. Cary, North Carolina.

Vasilenko T.F. 2016. Multidirecctional changes in the blood cholesterol in mammals of different species during pregnancy and lactation. IJSBAR 30(2):59-70.

Vincze B., Kutasi O., Baska F. \& Szenci O. 2015. Pregnancy-associated changes of sérum biochemical values in Lipizzaner Broodmares. Acta Vet. Hungarica 63(3):303-316. <http://dx.doi.org/10.1556/004.2015.028> <PMid:26551420> 